\title{
Study of the antibacterial properties of sulfated polysaccharides from brown algae Fucus vesiculosus
}

Ayrapetyan O.N. ${ }^{1,2}$, Zhurishkina E. $V^{1}$. , Obluchinskaya E.D. ${ }^{3}$, Kulminskaya A.A ${ }^{1}$., Lapina I.M ${ }^{1}$.

${ }^{1}$ National Research Center "Kurchatov Institute", B.P. Konstantinov Petersburg Nuclear Physics Institute, Gatchina, Russia;

${ }^{2}$ Saint-Petersburg National Research University of Information Technologies, Mechanics and Optics, St. Petersburg, Russia; ${ }^{3}$ Federal State Budgetary Scientific Institution of Murmansk Marine Biological Institute, Kola Scientific Center of the Russian Academy of Sciences, Murmansk, Russia

E-mail: ayrapetyan_on@pnpi.nrcki.ru

Key message. Two fractions of fucoidans were identified and characterized, and their effects on bacteria were investigated. The values of the minimum inhibitory concentration (MIC) were determined, and the effect on the formation of biofilms was studied.

Keywords: fucoidan, bacteria, biofilms, bacteriostatic action

The necessity of searching for new antimicrobial agents is due to the growing resistance of pathogenic strains to antibiotics. Brown algae, whose contain sulfated polysaccharides (fucoidans) with a wide range of biological activities, are currently being actively studied as a natural source of antibacterial compounds.

Purpose: To Study the antibacterial properties of two fractions of sulfated polysaccharides with different degrees of purification, emitted from brown algae Fucus vesiculosus.

The monosaccharide composition was determined by the HPLC method, the content of sulfates and uronic acids was determined by the turbidimetric method. MIC -by dilution on a tablet; determination of living and dead cellsspectrophotometry. Researching the biofilms-staining with a crystal violet dye.

Brown algae Fucus vesiculosus has been collected in the littoral of the Barents Sea. Polysaccharides were emitted in accordance with the technological scheme [1]. The chemical composition of the purified fucoidan fraction obtained as a result of processing the native fucopolysaccharide differed from the composition of the coarse fraction. The following bacteria were used as the research object: E. coli, B. licheniformis, S. epidermidis, and S. aigeis. The minimum inhibitory concentration of polysaccharides was determined. The growth curves of microorganisms during cultivation for 24 hours are constructed. [2] The Bacteriostatic effect of fucoidans was proved by the growth of microorganisms treated with polysaccharides when transferred from a liquid medium to an agarized one. During processing the bacterial cultures at the early stages of biofilms formation with fucoidans in MIC concentrations, a violation of their formation is observed. While at a low concentration of fucoidans (below MIC), film formation increases. [3]

\section{Исследование антибактериальных свойств сульфатированных полисахаридов из бурых водорослей Fucus vesiculosus}

Айрапетян О. $H^{1,2}$, Журишкина Е.В. ${ }^{1}$, Облучинская Е.Д. ${ }^{3}$, Кульминская А.А. ${ }^{1}$, Лапина И.М. ${ }^{1}$

${ }^{1}$ НИЦ «Курчатовский институт» - ПИЯФ, Гатчина, Россия; ${ }^{2}$ Научно-исследовательский институт механики, технологий и оптики, Санкт-Петербург, Россия; ${ }^{3}$ Мурманский морской биологический институт Кольского научного центра РАН, Россия

Аннотация. Были выделены и охарактеризованы две фракции фукоиданов, исследовано их воздействие на бактерии. Определены значения минимальной подавляющей концентращии (МПК), изучено влияние на формирование биопленок. Ключевые слова: фукоидан, бактерии, биопленки, бактериостатическое действие

Необходимость поиска новых антимикробных средств обусловлена ростом резистентности патогенных штаммов к антибиотикам. В качестве природного источника антибактериальных соединений в настоящее время активно исследуются бурые водоросли, которые содержат сульфатированные полисахариды (фукоиданы), обладающие широким спектром биологических активностей.

Цель: Исследование антибактериальных свойств двух фракций сульфатированных полисахаридов с разной степенью очистки, выделенных из бурых водорослей Fucus vesiculosus.

Моносахаридный состав был определен методом ВЭЖХ, содержание сульфатов и уроновых кислот - турбидиметрическим методом. МПК - методом разведений на планшете; определение живых и мёртвых клеток - спектрофотометрия. Изучение биопленок - окрашивание кристаллическим фиолетовым.

Бурые водоросли Fucus vesiculosus были собраны в литорали Баренцева моря. Полисахариды выделены в соответствии с технологической схемой [1]. Химический состав очищенной фракции фукоидана, отличался от состава грубой фракции (изменились соотношения моносахаридов, уменьшилось количество уроновых кислот). В качестве объекта исследования были использованы следующие бактерии: E. coli, B. licheniformis, S. epidermidis, S. aureus. Была определена минимальная подавляющая концентрация. Построены кривые роста микроорганизмов при культивировании в течение 24 часов. [2]. При обработке культур на ранних стадиях формирования биопленок фукополисахаридами в концентрациях МПК наблюдается нарушение их формирования. Тогда как при низкой концентрации фукоиданов (ниже МПК) происходит усиление пленкообразования. [3]

1. Пат. 2337571 Российская Федерация МПК А61K41 A61J; C01, C07, C08, C12N; C11D; C12N, A23L1/30, A23L 1/308

A23L1/337 Способ комплексной переработки бурых водорослей Облучинская Е.Д., заявитель и правообладатель; ММБИ КНЦ РАН, Б.И. № 31 (2008)

2. Foerster, M. Unemo, L.J. Hathaway, N. Low, C.L. Althaus, Time-kill curve analysis and pharmacodynamic modelling for in vitro evaluation of antimicrobials against Neisseria gonorrhoeae, BMC Microbiol. 16 (2016) 216

3. Djordjevic D, Wiedmann M, McLandsborough LA. Microtiter plate assay for assessment of Listeria monocytogenes biofilm formation. Appl. Environ. Microbiol. 2002; 68:2950-8 